\title{
Differentiated Instruction: Bibliometric Map of Literature
}

\author{
Halil COBAN ${ }^{1}$
}

\begin{abstract}
The aim of this study is to analyze the publications in the literature on differentiated instruction. 667 publications published in various sources in the Web of Science database until November 2020 were analyzed using the bibliometric analysis method. Analyzes were made with Vos viewer software. Common keywords used by the authors, the bibliographic coupling of countries, institutions, sources, authors and publications and co-citation of authors, references and sources were analyzed and visualized via the software. As a result of the analysis, it was determined that the concept of differentiated instruction is frequently used together with the keywords as differentiation, curriculum, inclusive education, universal design for learning (UDL), learning styles, assessment, professional development. In the literature of differentiated instruction, Ghent University and Brussel University stand out from the other universities. In addition, "teaching and teacher education", "teachers and teaching" and "educational leadership" journals that include publications related to the differentiated instruction are prominent journals. As a result of the most influential author analysis, Tomlinson came to the fore as the author of the most cited publications. At the same time, the USA and Canada stand out as the leading countries in publications in the field of differentiated instruction.
\end{abstract}

Key Words: Bibliometric analysis, Differentiated instruction, Bibliometric mapping.

\section{Farklılaştırılmış Öğretim: Literatürün Bibliyometrik Haritalaması}

Öz

$\mathrm{Bu}$ çalışmanın amacı, farklılaştırılmış öğretim ile ilgili literatürdeki yayınları incelemektir. Web of Science veri tabanında Kasım 2020'ye kadar çeşitli kaynaklarda yayınlanan 667 yayın, bibliyometrik analiz yöntemi kullanılarak analiz edilmiştir. Vosviewer yazılımı kullanılarak analizler yapılmıştır. Yazarlar tarafindan kullanılan ortak anahtar kelimeler, ülkelerin, kurumların, kaynakların, yazarların ve yayınların bibliyografik eşleşmeleri ve yazarlara, referanslara ve kaynaklara yapılan ortak atıflar yazılım aracılığılla analiz edilerek görselleştirilmiştir. Yapılan analizler sonucunda farklılaştırılmış öğretim kavramının en çok farklılaştırma, öğretim programı, kapsayıcı eğitim, evrensel öğrenme tasarımı (UDL), öğrenme stilleri, değerlendirme, mesleki gelişim anahtar kelimeleriyle birlikte kullanıldığ tespit edilmiştir. Farklılaştırılmış öğretim alanında yapılan yayınlarda "Ghent University" ve "Brussel Universty" öne çıktığ1 görülmüştür. Ayrıca, farklılaştırılmış öğretimle ilgili yayınların yer aldığı dergilerden öne çıkanların "teachers and teaching" and "educational leadership" olduğu tespit edilmiştir. Alanda en etkili yazar analizinin bir sonucu olarak Tomlinson, en çok alıntı yapılan yayınların yazarı olarak öne çıkmıştır. Aynı zamanda farklılaştırılmış öğretim alanında yapılan yayınların kökeni olarak ABD ve Kanada ülkeleri öne çıkmıştır.

Anabtar Kelimeler: Bibliyometrik analiz, Farklılaştırılmış öğretim, Bibliyometrik haritalama

\section{Atıf İçin / Please Cite As:}

Çoban, H. (2022). Differentiated instruction: bibliometric map of literature. Manas Sosyal Araştırmalar Dergisi, 11(1), 46-62.

Geliş Tarihi / Received Date: 28.01.2021

Kabul Tarihi / Accepted Date: 13.09.2021

\footnotetext{
${ }^{1}$ Dr. - Türkiye-Milli Eğitim Bakanlığı, cobanhalil@hotmail.com

iD ORCID: 0000-0001-6807-1380
} 


\section{Introduction}

After examining the factors improving students' learning and affect their success, it can be stated among the factors like the classroom size, teachers' experience and others the quality of the teaching plays the great role (Park, 2005, s. 88-89). The quality of teaching is closely related to the planning made by taking into account the individual differences, abilities, readiness, interests and needs of the students. In that regard, differentiated instruction stands out as a modern approach that prioritizes students' interests, needs, abilities and knowledge (Hollas, 2005; Valiandes, 2015, p. 17).

There is a large consensus in the literature on both the components and the applications of differentiated instruction (Heacox, 2002; Tomlinson, 1999; Tomlinson, \& Allan, 2000). Tomlinson (2000, s. 2) defines differentiated instruction as a proactive approach that provides opportunities for students to learn in the most efficient way and is about the points students need to learn, the ways of learning and the ways of revealing what they have learned. In other words, differentiated instruction enables the program to be compatible with readiness levels, interests, needs and learning profiles of the students through adaptations in the content, process and product dimensions of the program (Hall, Strangman, \& Meyer, 2003, p. 2-3; Tomlinson, 2000, s. 5; Tomlinson, \& Jarvis, 2009).

Since differentiated instruction is an approach that takes students' individual development into account, it is not only facilitates the conditions in which students can achieve success, but also contributes to their personal development (Tomlinson, \& Allan, 2000, p. 4-5). It provides these through flexible learning environments, assessment of needs in the process, flexible groups, individual challenging tasks and cooperative learning groups (Tomlinson, 1999, p. 2-3; Tomlinson, \& Allan, 2000, p. 5). In summary, the four pillars that form the basis of differentiated instruction can be expressed as focusing on the basic ideas and skills in the content areas, sensitivity to the individual differences of students, the integration of teaching and evaluation, and the arrangement of content, processes and products in line with individual interests and needs (Tieso, 2003, p. 34; Tomlinson, 1999, p. 4).

The aim of this study is to contribute to the development of the literature in this area by analyzing the publications on differentiated instruction. Bibliometric analysis was used to reveal the trends of the publications. Bibliometric methods reveal the orientation of research in the scientific area, developments in the literature and the structure of the field with various classifications (Cobo, Lopez-Herrera, HerreraViedma, \& Herrera, 2011, p. 1382). Bibliometric methods are generally used for two purposes; performance analysis and scientific mapping (Demir-Erigüç, 2018, p. 97). Performance analysis reveals the performances of institutions or countries regarding their publications; scientific mapping tries to identify the dynamics of the area (Noyon, Moed, \& Raan, 2006, p. 592). For example, it is possible to analyze publications from their sources to keywords, from published countries to authors, from citations to affiliated institution. In fact, by making more advanced analysis of the publications, based on co-author mapping of the publications, common citations and sources, common keywords and bibliographic matching of authors, institutions and countries can create visually useful maps.

In this study, the Web of Science (WoS) database of scientific publications, which is the most prestigious in the world, was used. The WoS database is one of many databases like Scopus, Google Scholar. However, WoS was preferred in the research because it contained a large number of journals with a high impact factor of social science and it offers researchers facilities for analysis.

\section{Method}

\section{Aim and Importance of the Research}

In this study, the aim is to examine the trends in the field of differentiated instruction through bibliometric mapping method by analyzing the authors, number of publications, keywords, journals, countries and citation numbers of publications in the field. Bibliometric analysis allows the publications in the field and some variables related to the publications to be systematically examined. Bibliographic researches made accordingly, make it easier to follow the developments in the field (Cobo et all., 2011, p. 1383). This study is also important as it is the first bibliographic study in the national literature on differentiated instruction. 


\section{Searching Strategy}

Using the advanced search feature of the WoS database, all publications until November 2020 were searched using the query "differentiated instruction" "differentiated learning", "differentiated teaching" and "differentiated classroom" without limiting publication type and the year. As a result, a total of 667 publications formed the analysis unit.

\section{Data Analysis}

The publications included in the study were presented by bibliometric visualization method based on the mathematical and statistical relationships among themselves (Hoffman \& Holbrook, 1993). Using the data set, common keywords used by the authors are bibliographic coupling of countries, institutions, authors, publications, and co-citations of authors, institutions and publications were analyzed through Vosviewer software. The threshold value was used in all analyzes to reveal meaningful relationships, since not using the threshold value will cause a messy appearance and the formation of visuals that are very difficult to interpret (White, \& McCain, 1998, p. 332). The analysis of common keywords used by the authors is important in revealing the subfields and trends of the research field (Özçınar, 2017, p. 164). Citing the works of the authors by other studies is closely related to how much it affects the subsequent research (Al, 2008, p. 34-35). Examining the relationship between the cited sources is possible with citation analysis (Smith, 2007). Citation analysis is important in determining the effective ones among the publications, authors and journals, revealing their relations with each other and revealing the historical status of the research field (Goksu, 2020, p. 4). Citation analysis can basically be done with two approaches; it is a co-citation and bibliographic coupling (Çilhoroz, \& Arslan, 2018, p. 543). Analyzes made in this research were carried out using "Bibliographic Coupling" and "Co-Citation" techniques included in the Vosviewer software. Bibliographic coupling is the citation of the same source from two separate sources (Garfield, 1988, p. 162; Kesler, 1963). The more common publications these two sources cite, the higher the strength of the bibliographic coupling increases. The co-citation approach is about citing a source to two separate sources simultaneously (Garfield, 1988, p. 162). In this case, the more references cited by two sources cited at the same time, the higher the common citation strength increases. Accordingly, while there is no change in the bibliographic coupling strength over time, the co-citation strength is affected by the publications made over time (Small, 1973, p. 265; Ukşul, 2016, p. 18).

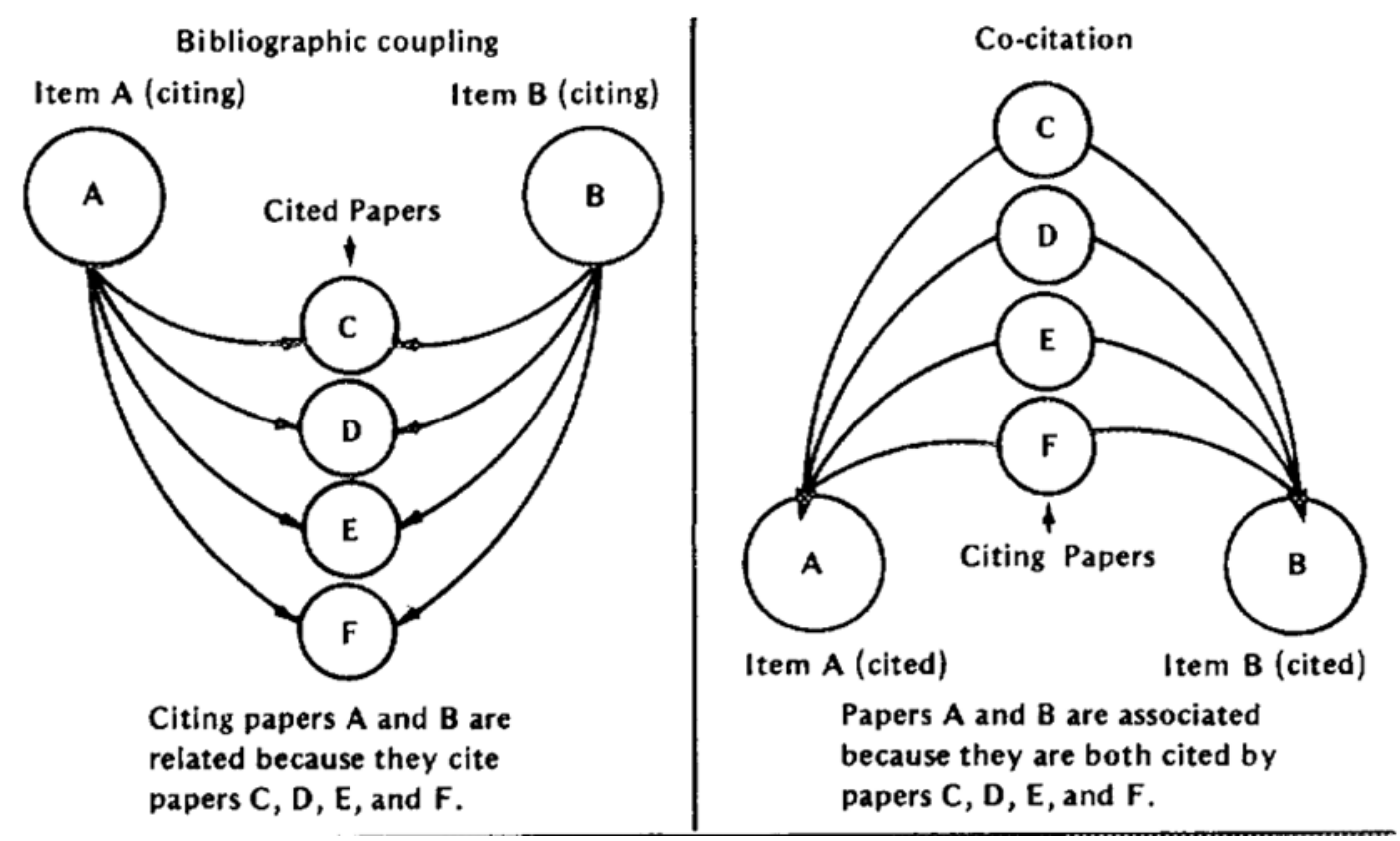

Figure 1. Bibliographic coupling vs. co-citation (Garfield, 1988, p. 162)

\section{Findings}

\section{Bibliographic Coupling of Sources}

The bibliographic coupling of the sources is shown in Figure 1 with the "density visualization". Sources that have at least 5 publications were included in this study. It was observed that 14 of the 431 sources provided the given threshold value. Bibliographic coupling of all sources and their total links' 
strength (TLS) to other publications was calculated. The first two most influential journals are "teaching and teacher education" and "teachers and teaching". The first of these sources has 13 publications on differentiated instruction, while the second has 6 publications. At the same time, the first source has 158 citations, while the second has 54 citations. The first source has more TLS (685) than the second source (403). The determinations and calculations of the other 12 sources in terms of the number of publications, the number of citations and the TLS are shown in Table 1;

Table 1. Bibliographic Coupling of Sources

\begin{tabular}{|c|c|c|c|}
\hline Source & $\begin{array}{l}\text { Number of } \\
\text { Publication }\end{array}$ & $\begin{array}{c}\text { Number of } \\
\text { citiation }\end{array}$ & TLS \\
\hline teaching and teacher education & 13 & 158 & 685 \\
\hline teachers and teaching & 6 & 54 & 403 \\
\hline studies in educational evaluation & 5 & 43 & 399 \\
\hline international journal of instruction & 7 & 3 & 380 \\
\hline international journal of inclusive education & 10 & 69 & 298 \\
\hline journal of advanced academics & 10 & 109 & 146 \\
\hline journal for the education of the gifted & 8 & 137 & 172 \\
\hline professional development in education & 5 & 41 & 128 \\
\hline inted 2016 & 5 & 3 & 111 \\
\hline gifted child quarterly & 6 & 112 & 105 \\
\hline theory into practice & 5 & 135 & 97 \\
\hline reading teacher & 6 & 82 & 55 \\
\hline international journal of emerging technologies in learning & 5 & 7 & 1 \\
\hline russian education and society & 5 & 1 & 0 \\
\hline
\end{tabular}

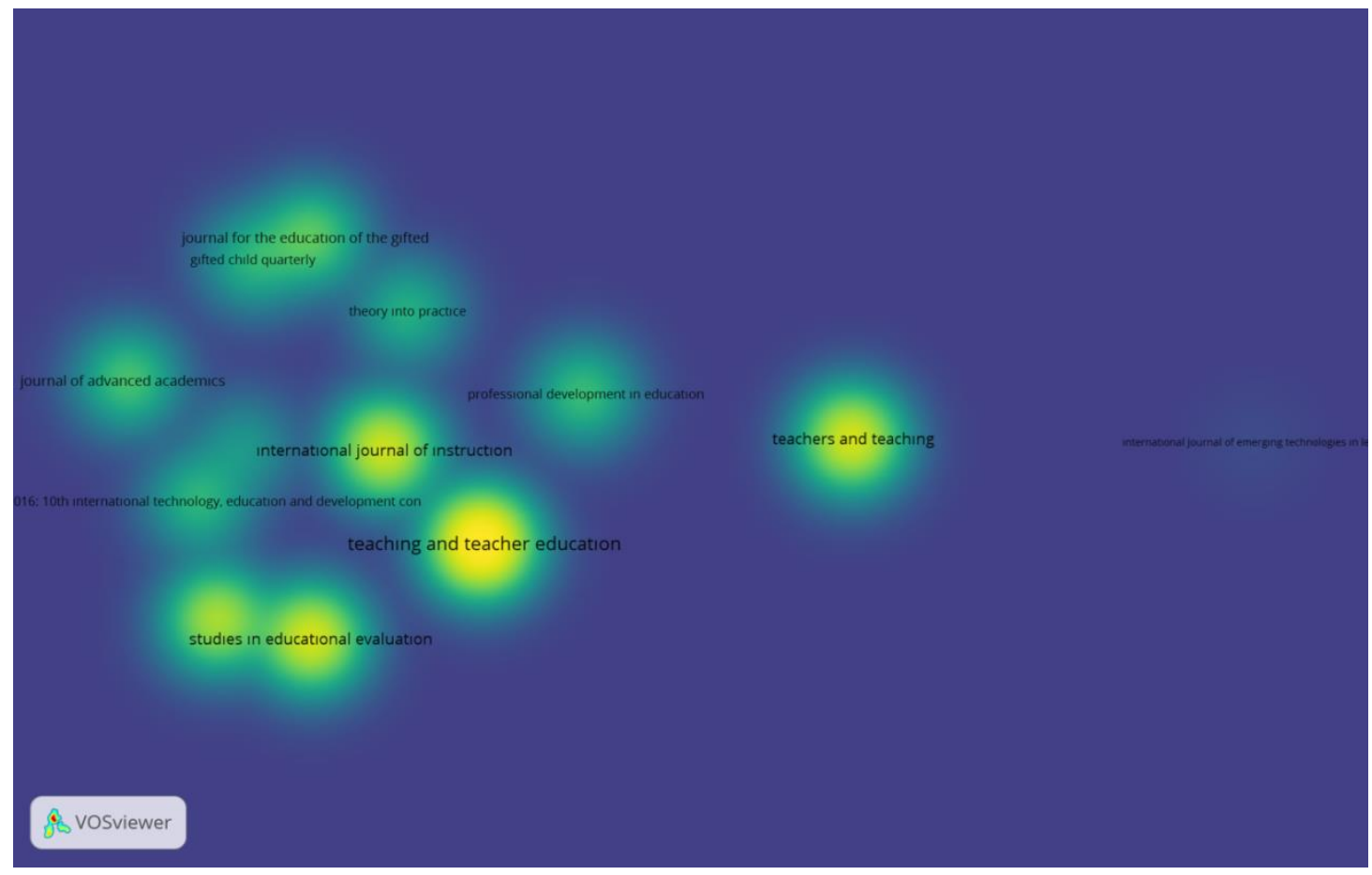

Figure 1. Bibliographic coupling of sources

\section{Bibliographic Coupling of Countries}

Bibliographic coupling of countries has been shown by overlay visualization in figure-2. Countries with at least 10 publications have been included in the analysis. It is seen that 16 out of 73 countries with publications related to the field meet this requirement. Bibliographic coupling TLS with other countries was calculated for each country. The USA comes first in this list, with 252 publications, 2814 citations and 8358 TLS. The determinations and calculations of the other countries in terms of the number of publications, the number of citations and the TLS are shown in table-2; 
Table 2. Bibliographic coupling of countries

\begin{tabular}{|c|c|c|c|}
\hline Countries & Number of Publication & Number of citation & TLS \\
\hline USA & 252 & 2814 & 8358 \\
\hline Canada & 39 & 221 & 3210 \\
\hline Belgium & 18 & 217 & 2916 \\
\hline Australia & 21 & 179 & 2151 \\
\hline Netherlands & 20 & 84 & 2055 \\
\hline Turkey & 13 & 25 & 1932 \\
\hline Greece & 19 & 58 & 1530 \\
\hline Germany & 20 & 26 & 1487 \\
\hline China & 29 & 37 & 1192 \\
\hline South Africa & 14 & 61 & 1095 \\
\hline Singapore & 10 & 37 & 1084 \\
\hline England & 18 & 100 & 536 \\
\hline Romania & 20 & 69 & 450 \\
\hline Spain & 12 & 26 & 265 \\
\hline Brazil & 12 & 17 & 92 \\
\hline Ukraine & 10 & 7 & 63 \\
\hline
\end{tabular}

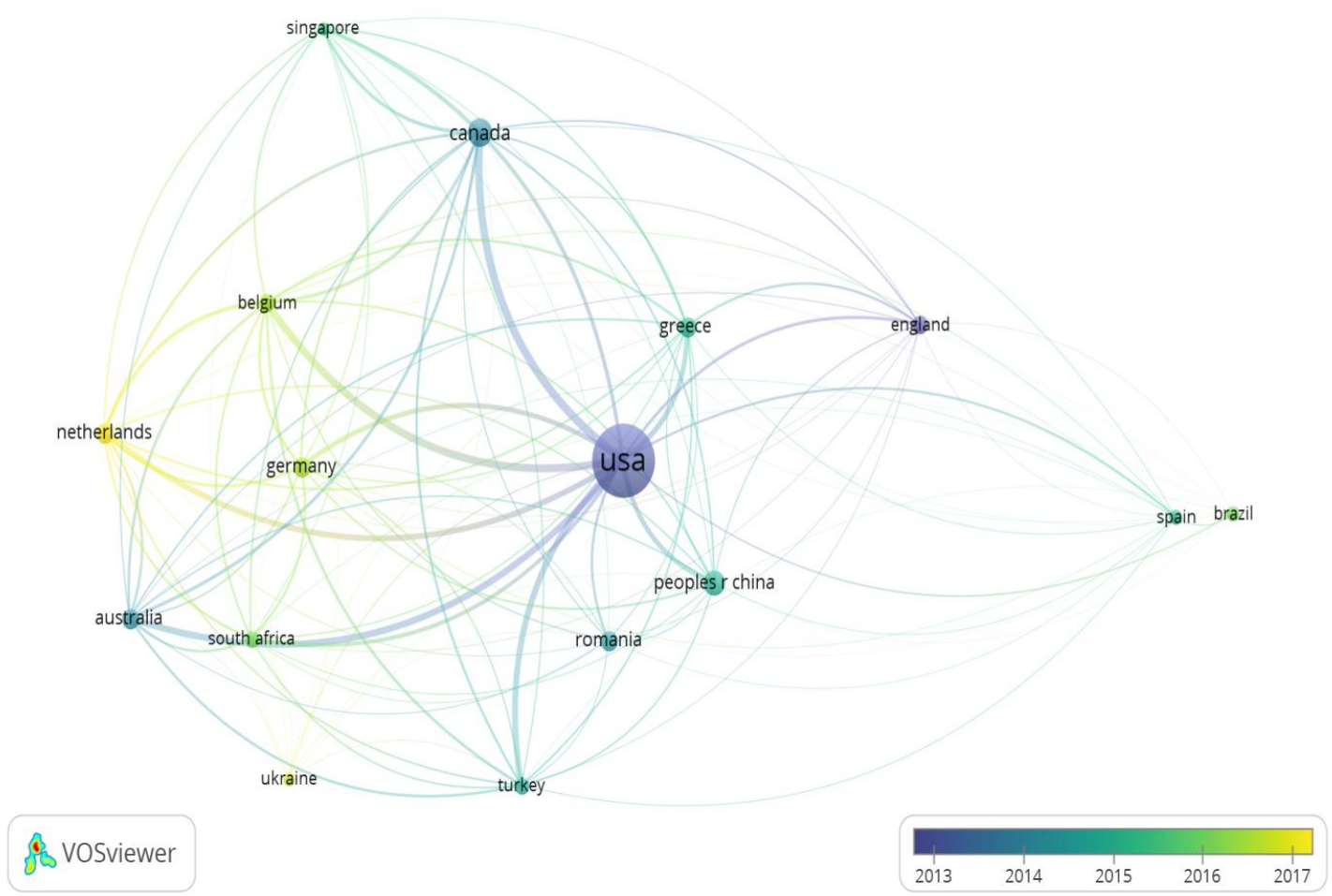

Figure 2. Bibliographic Coupling of Country

When the colors in Figure- 2 are examined, it shows the years of publications related to the countries. The results show that the Netherlands and Ukraine stand out among the publications in this field in recent years.

\section{Co-occurrences of the Author Keyword}

The common occurrences of the authors' keywords have been shown in figure-3. Keywords that have emerged as common at least 5 times were included in the analysis. It was determined that 57 out of 1727 words fulfil this requirement. By considering all keywords, the co-occurrence TLS was calculated in relation to other keywords. Of the keywords, "differentiated instruction" has emerged as the strongest keyword with 164 occurrences and total link strength 128. While expressing the "differentiated instruction" concept in both titles and keywords, the preferred expression comes to the fore as "differentiated instruction". 


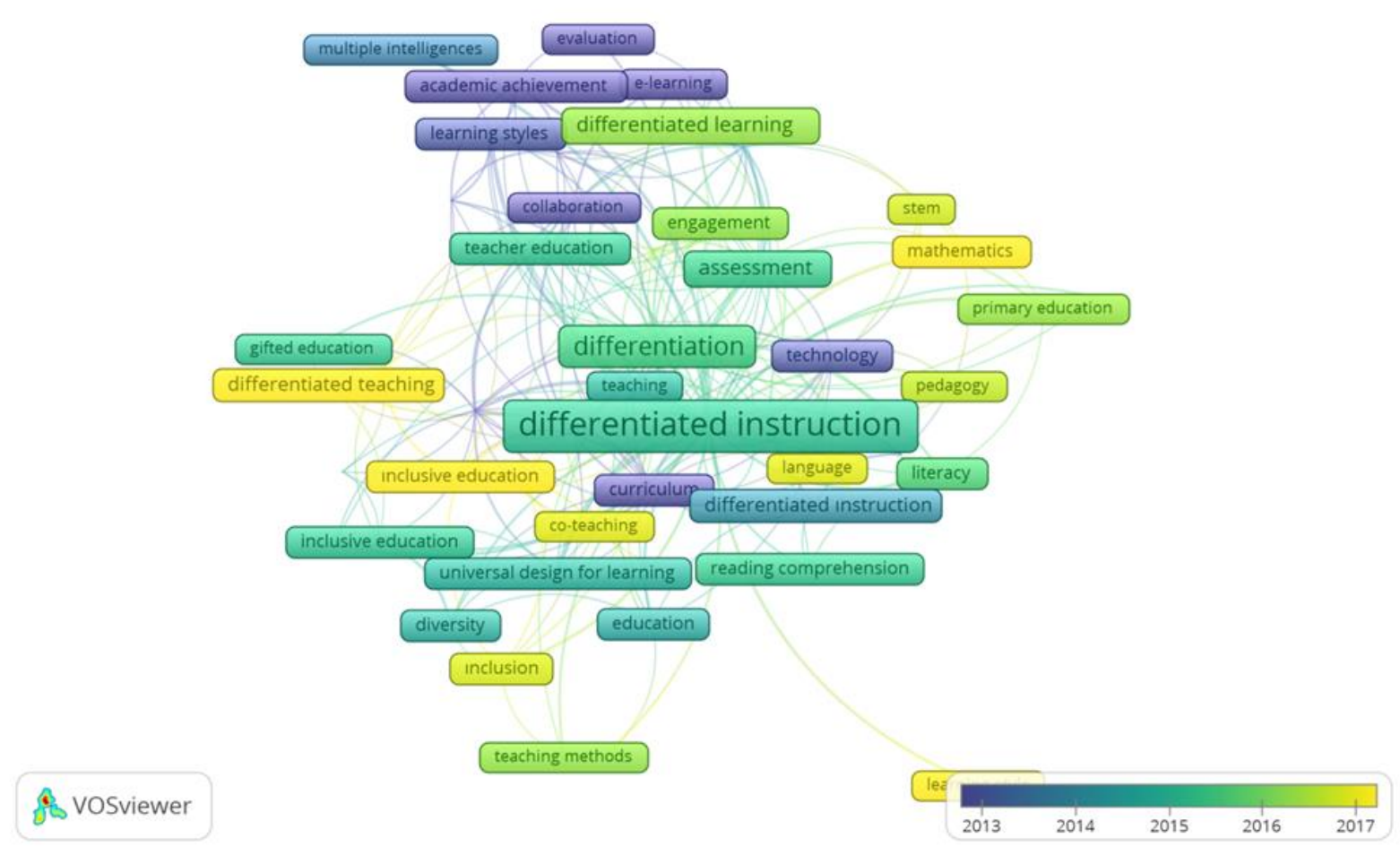

Figure 3. Co-occurrences of the Author Keyword

The analysis of the co-occurrence of keywords reveals the trend by a year and gives an idea of trend research topics. Mathematics, language, inclusive education and learning style have come to the fore in the last period (2016-2020). It was observed that the keywords were collected under 9 clusters in total, with each cluster consisting of words used together, which are linked to each other. Keywords in clusters provide information on relevant topics studied in the field (Goksu, 2020). The keywords in each cluster are given as follows to show the number of occurrences of the first number given in parentheses and the second number to show TLS; in the first cluster, curriculum $(9,21)$, differentiation $(51,61)$, flipped classroom $(8,8)$, instruction $(6,11)$, kindergarten $(5,4)$, language $(5,6)$, literacy $(9,11))$, reading $(7,9)$, reading comprehension $(7,6)$, teaching $(6,9)$, in the second cluster, attitudes $(6,13)$, differentiated teaching $(12,7)$, diversity $(7,9)$, gifted education $(5,5)$, inclusion $(19,31)$, inclusive education $(10,12)$, physical education $(6,7)$, self-efficacy $(6,5)$, universal designing for learning $(10,16)$. In the third cluster academic achievement $(7,13)$, evaluation $(5,4)$, higher education $(8,11)$, learning styles $(11,18)$, multiple intelligences $(5,5)$, pre-service teachers $(5,12)$, teaching strategies $(6,15)$. In the fourth assessment $(23,33)$, engagement $(7,15)$, mathematics $(8,9)$, motivation $(9,16)$, professional development $(15,20)$, stem $(5,4)$, teacher education $(8,22)$. In fifth cluster formative assessment $(7,7)$, middle school $(6,9)$, pedagogy $(5,5)$, special education $(13,23)$, teacher training $(6,7)$, technology $(9,16)$. In sixth cluster education $(10,11)$, inclusion $(9,9)$, learning $(7,4)$, teaching methods $(6,5)$, training $(6,4)$. In seventh cluster co-teaching $(5,10)$, disability $(6,12)$, early childhood $(5,13)$, inclusive education $(11,15)$. In eighth cluster differentiated instruction $(164,128)$, learning style $(5,3)$, primary education $(5,10)$, secondary education $(5,4)$. In ninth cluster collaboration $(6,13)$, differentiated learning $(19,7)$, e-learning $(5,8)$, personalised learning $(5,5)$.

\section{Bibliographic Coupling of Authors}

The bibliographic coupling of the authors who publish in the field is shown in figure-4. Authors with at least 3 publications were included in the analysis. It has been determined that 26 of 1498 authors have at least 3 publications. The TLS with other authors was calculated for each author. As a result of the analysis, R. Vanderlinde ranked first with 4 publications 9 citations and 1896 total links' strength. Authors who have 4 publications are listed as follows; 
Table 4. Bibliographic Coupling of Authors

\begin{tabular}{llll}
\hline Authors & Publication & Number of citations & TLS \\
\hline R. Vanderlinde & & 9 & 1896 \\
F. Guay & & 57 & 739 \\
A. Roy & 57 & 739 \\
P. Valois & 57 & 739 \\
K. Struvyen & 34 & 403 \\
T. Dejager & 23 & 149 \\
J. Marshall & 0 & 96 \\
A.M. Mujea & 3 & 25 \\
O. Synekop & 6 & 5 \\
\hline
\end{tabular}

The colors seen in Figure-4 show the distribution of the publications by years. Accordingly, it reveals that the authors who have made researches in the field of differentiated instruction in recent years are $\mathrm{O}$. Synekop, H.dack, A. Zusho, J. Meirink, R. Vanderlinde, P. Van Avermaet, I. Roose and W. Vanteighem.

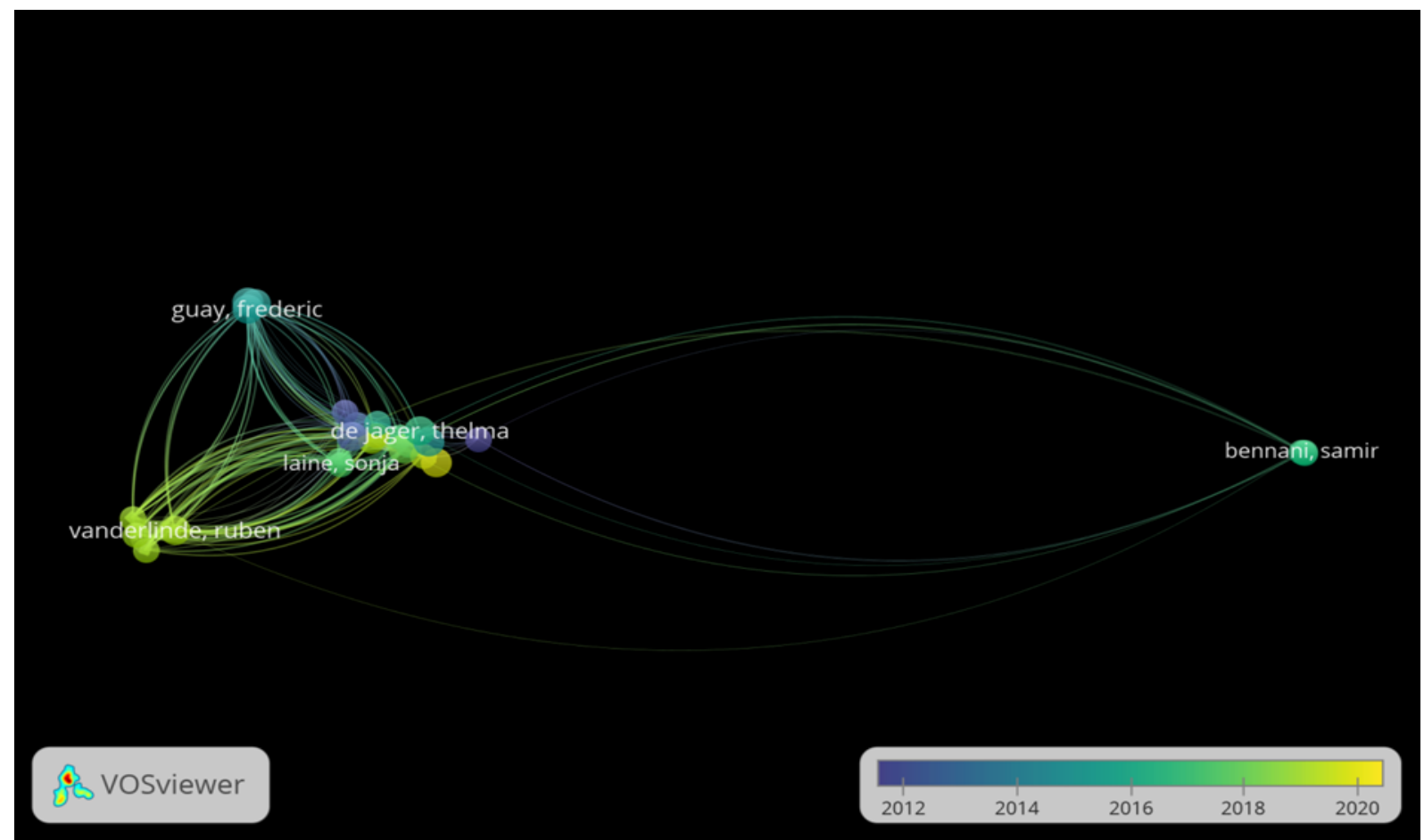

Figure 4. Bibliographic coupling of authors

\section{Bibliographic Coupling of Institution}

The bibliographic coupling of the institutions is shown in figure-5 with the overlay visualization. Those with at least 5 publications among the institutions were included in the analysis. Accordingly, it was observed that 22 out of 697 institutions provided threshold. The TLS formed as a result of bibliographic coupling of all institutions with other institutions was calculated. According to the analysis results, Ghent University ranks first with 9 publications, 147 citations and 1541 TLS. Table-4 shows the number of publications, the number of citations and the TLS from other universities;

\begin{tabular}{lccc}
\hline Institutions & Number of Publication & Number of citations & TLS \\
\hline Ghent Uni. & 9 & 147 & 1541 \\
Brussel Uni. & 8 & 43 & 1400 \\
Amsterdam Uni. & 5 & 19 & 660 \\
Groningen Uni. & 6 & 21 & 552 \\
Virginia Uni. & 11 & 195 & 524 \\
Leiden Uni. & 7 & 9 & 483 \\
Ohio State Uni. & 6 & 87 & 348 \\
Connecticut Uni. & 7 & 125 & 342 \\
Ottawa Uni. & 5 & 13 & 338 \\
Melbourne Uni. & 5 & 10 & 325 \\
Carolina Uni. & 5 & 5 & 203 \\
\hline
\end{tabular}




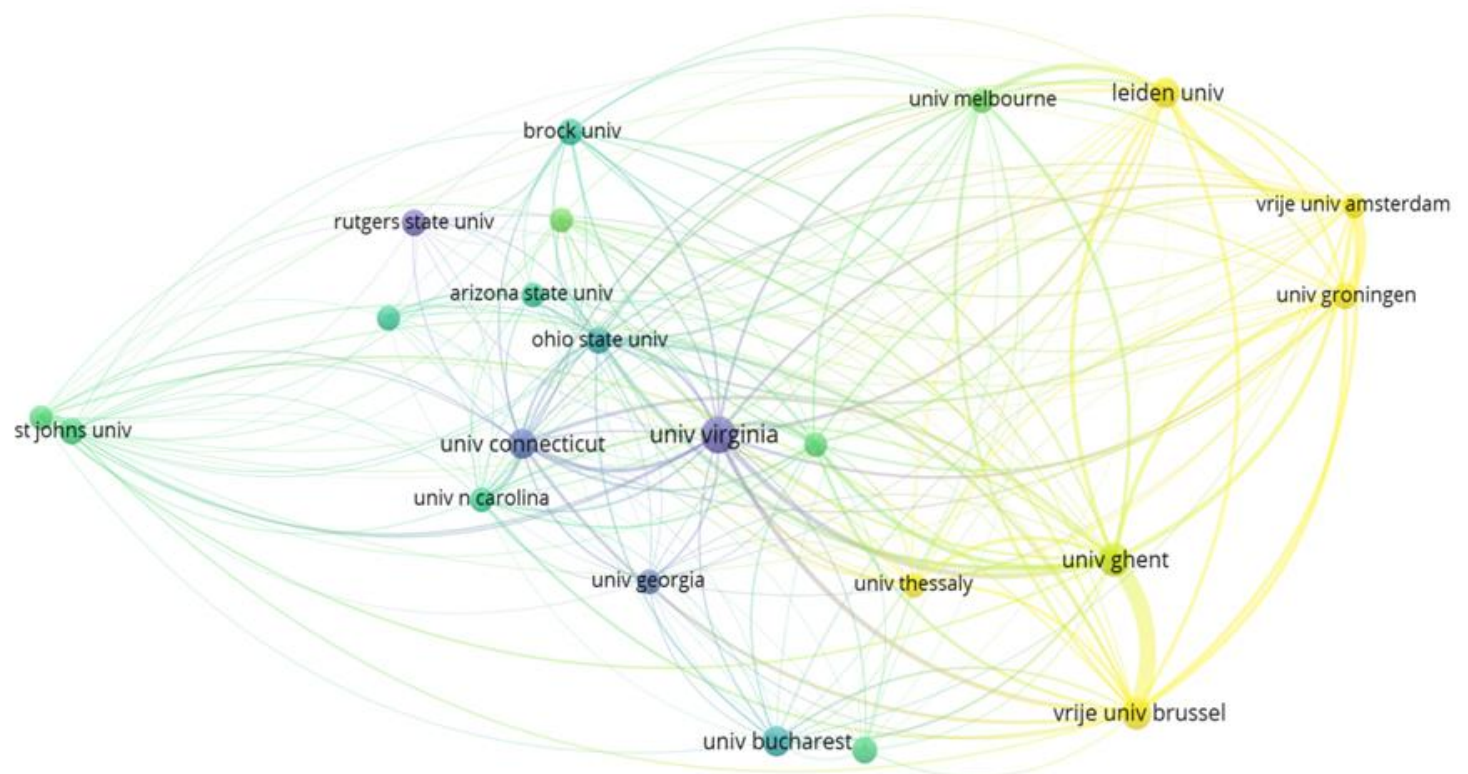

VOSviewer

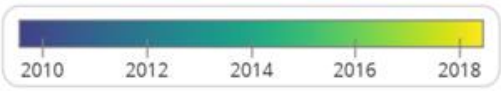

Figure 5. Bibliographic Coupling of Institution

When Figure- 5 is examined, different colors show the publication years of the studies made from these institutions. The results show that the researches in the field have been carried out in the recent years, especially in Brussel University, Groningen University, Amsterdam University, Leiden University and Thessaly University.

\section{Bibliographic Coupling of Publications}

Bibliographic coupling of the publications is shown in figure-6. Publications with at least 50 citations were included in the analysis. It has been determined that 16 out of 667 publications on differentiated instruction fulfil this requirement. For each publication, the total links' strength was calculated in relation to other publications. The strongest publication is that of the author of Santamaria (2009) with 52 citations and 20 total links' strength. The rankings of the other authors are as follows: the first of the numbers given in parentheses is the year of publication, the second is the number of citations and the third is the total links' strength; Reis vd. (2011; 76; 12), De neve vd. (2015; 51; 11), Dixon vd. (2014; 53; 10), Subban (2006; 72;10), Wertheim vd. (2002; 70; 9), Soodak vd. (1998; 147; 8), Baglieri vd. (2004; 54; 4), Vaughn vd. (1998; 83; 4), Westberg vd. (1993; 54; 3), Davies vd. (2013; 320; 1), Valli vd. (2007; 262; 1), Iacopini vd. (2012;74;0), Goudas vd. (1995; 83;0), Tomlinson (1999; 71; 0). 


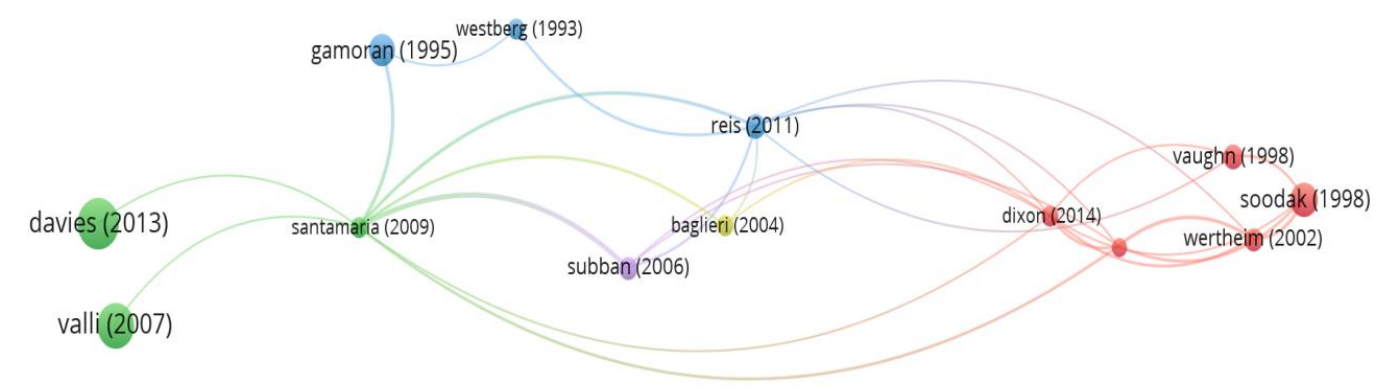

\section{VoSviewer}

Figure 6. Bibliographic Coupling of Publication

When Figure- 6 is examined, the publications that are particularly strongly linked to each other are categorized into 5 clusters. However, it is seen that only one author's publication exists in two of the clusters. In this respect, it can be stated that 3 clusters with which the publications are related are categorized. In the first cluster, Valli et al. (2007), Davies et al. (2013), Santamaria (2009) authors' publications, in the second cluster Vaughn et al. (1998), Wertheim et al. (2002), Soodak et al. (1998), Dixon et al. (2014), De neve et al. (2015), and in the third cluster, Westberg et al. (1993), Reis et al. (2011) and Gamoran et al. (1995), in the fourth cluster, Baglieri et al. (2004) and the fifth cluster Subban (2006) authors' publications included.

\section{Co-citation of References}

Among the 20307 cited references, at least 20 times were determined as the common citation threshold value and 20 references were found that met this threshold. The most co-cited reference is the research by Tomlinson (2001) with a total of 90 citations. However, the first 5 publications with the most co-citations are as follows, with the first issue in parentheses the year of publication and the second number of citations; Tomlinson (2001; 90), Tomlinson (2003; 81), Tomlinson (1999; 92), Tieso (2005; 29), Subban $(2006 ; 34)$. It is seen that three of the first 3 publications with the most co-citations belong to Tomlinson. The network and density visualization of the cited references are shown in figure- 7 and figure8. 


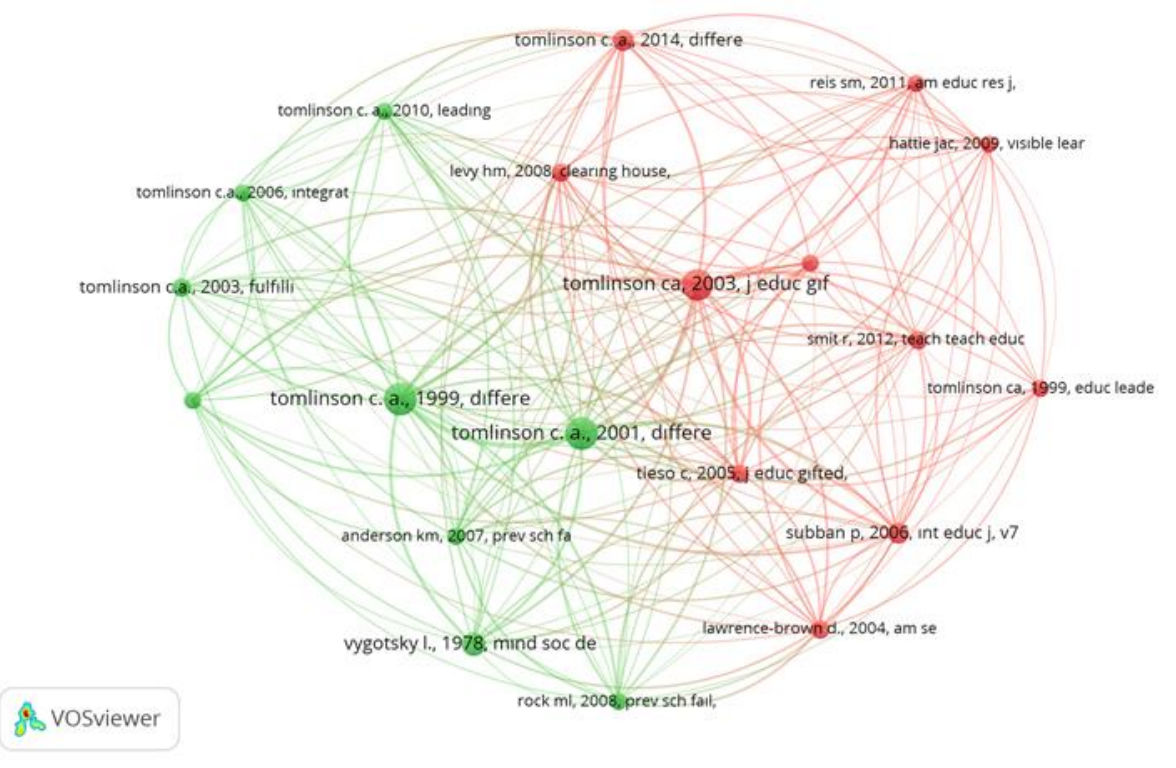

Figure 7. Co-citation of References

When the figure- 7 is examined, it is seen that the most cited authors among themselves are shown in 2 groups with 2 different colors.

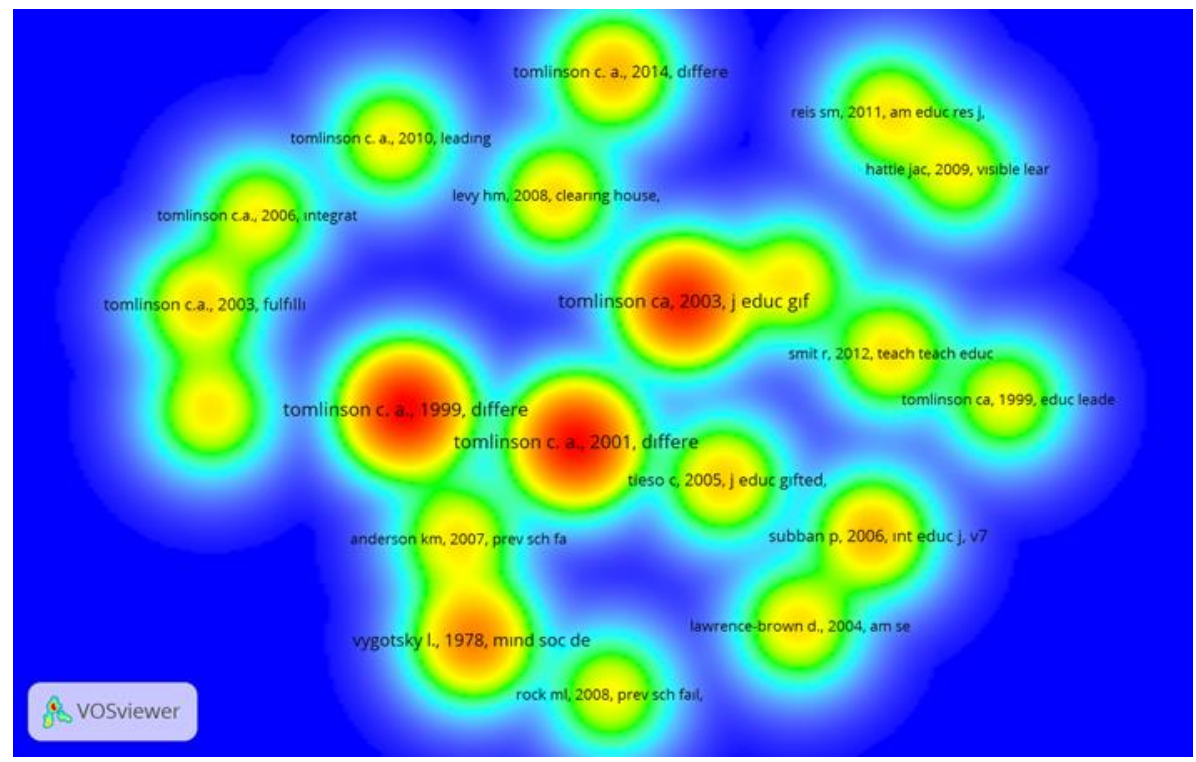

Figure 8. Co-citation of References

When the density visualization (figure-8) is examined, it is seen that the publications with the highest co-citation strength are the references of the same author (Tomlinson) in 1999, 2001 and 2003.

\section{Co-citation of Sources}

Among 10687 sources, 20 sources with at least 100 citations were included in the analysis. The first 3 references with the most co-citations are as follows, with the first number in parentheses showing the number of citation and the second showing TLS; "teacher and teaching education (383; 3747)", "educational leadership $(261 ; 2420)$ " and "journal for the education of the gifted $(197 ; 2107)$ ". The network and density visualization of the cited sources are shown in figures 9 and 10. 


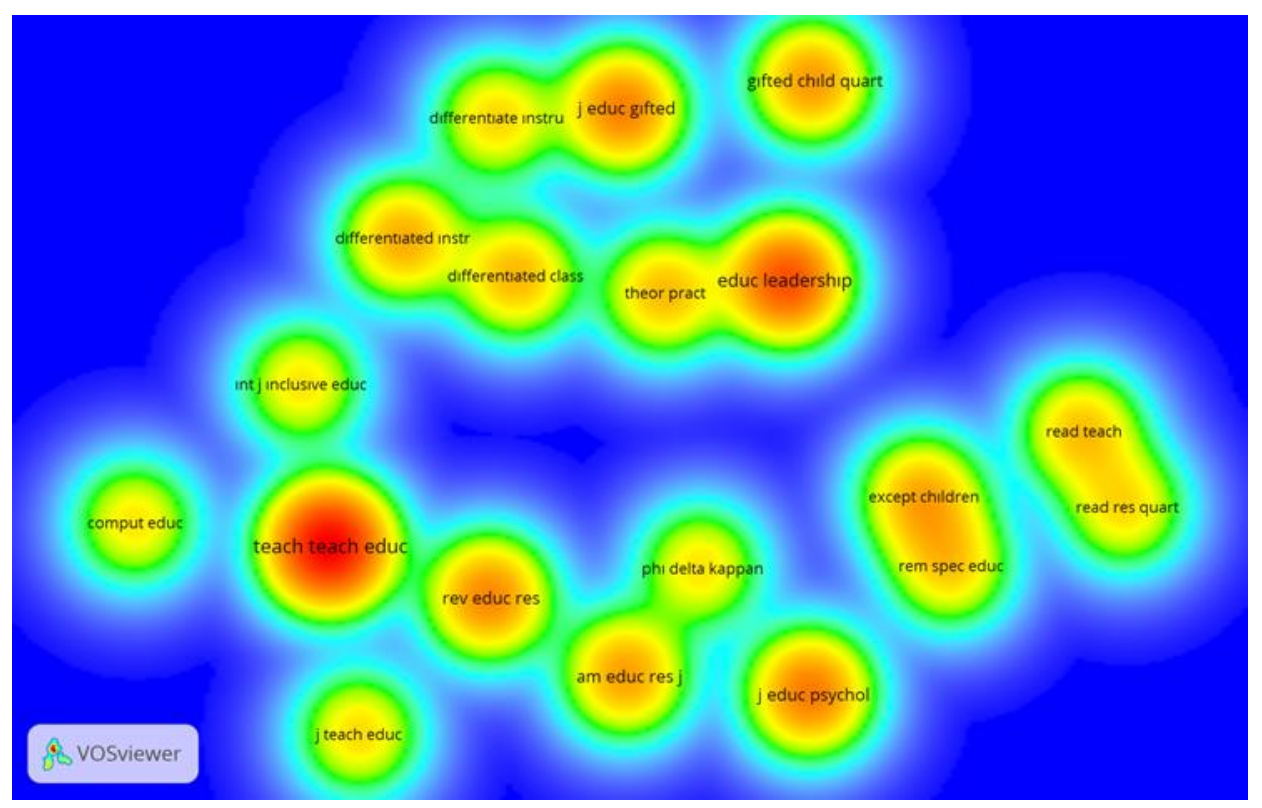

Figure 9. Co-citation of Sources

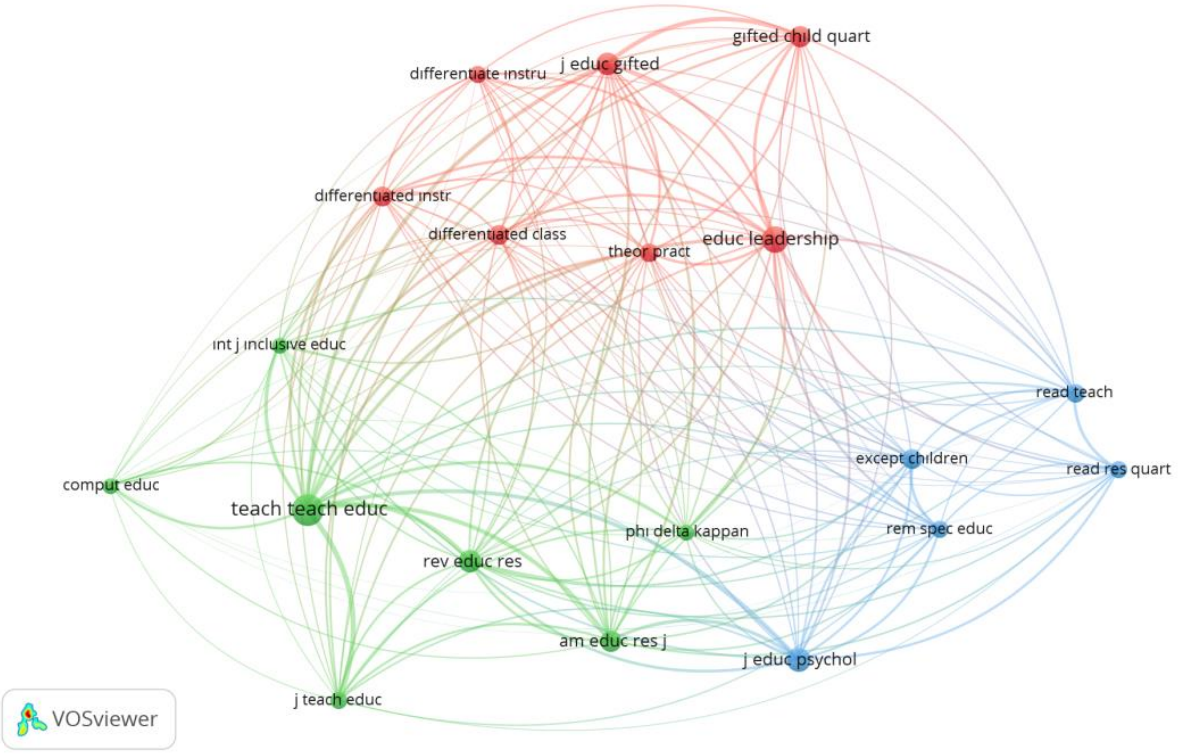

Figure 10. Co-citation of Sources

When the figure-10 is examined, it is seen that the most cited sources among themselves are shown in 3 groups with 3 different colors.

\section{Co-citation of authors}

Of all authors with a co-citation of 13882, at least 30 co-citations were determined as threshold and 26 authors meeting this threshold were identified. Among these authors, Tomlinson who first used the concept of differentiated instruction has the most co-citation strength with 687 citations and 2137 cocitation strength. After Tomlinson, the first 3 authors with the most co-citations were identified as Gardner (77,376), Reis (62,365) and Vygotsky (63,302); respectively the first of the numbers given in parentheses showing the number of citations and the second showing the number of co-citation strength. The network and density visualization of the co-cited authors are shown in figure 11 and figure 12; 


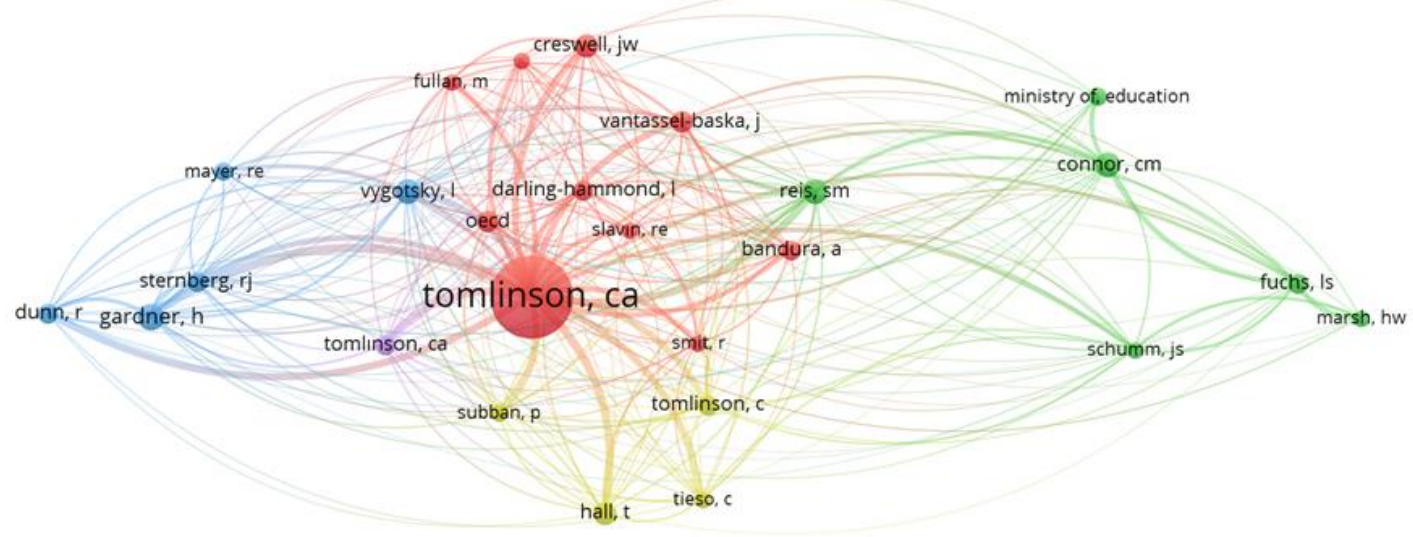

\& Vosviewer

Figure 11. Co-citation of Authors

When the figure-11 is examined, it is seen that the most cited authors among themselves are shown in 4 groups with 4 different colors.

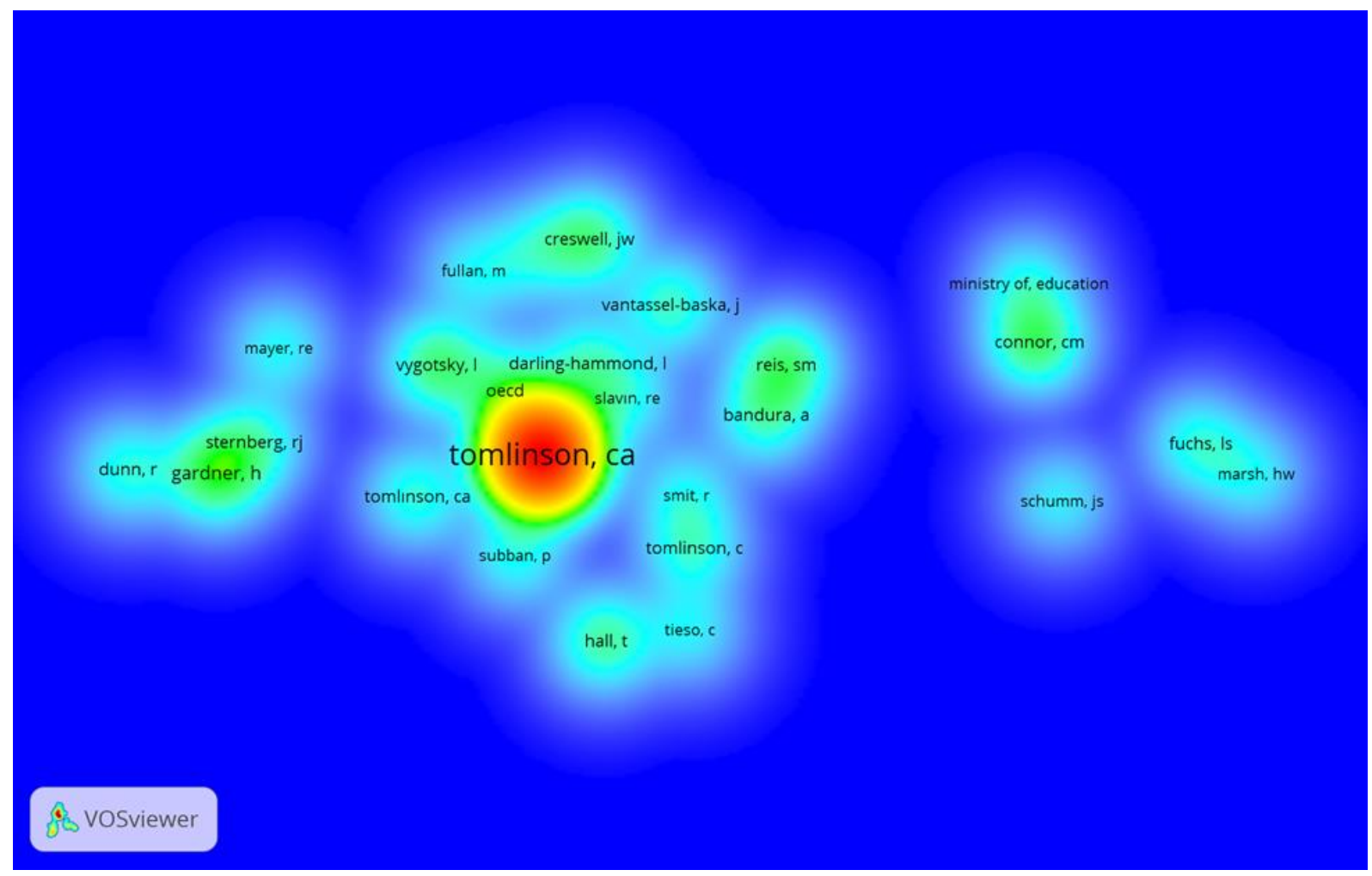

Figure 12. Co-citation of Authors

When figure-12 is examined it is seen that Tomlinson has the most co-citation strength among the other authors. 


\section{Results, Discussions And Suggestions}

In this study, bibliometric analysis was used in order to reveal the features of the publications, to determine the existing clusters, to make classifications and to reveal the trends regarding differentiated instruction. For this purpose, SSCI, SCI-Expanded, AHCI and ESCI in WoS databases were scanned. Bibliographic data was analyzed using evaluation techniques and visualized through the Vos viewer. Cooccurrence of author keywords, bibliographic coupling of sources, authors, countries, institutions and publications and co-citation of references, authors and sources were analyzed and visualized.

In the bibliographic coupling of the keywords used in common by the authors, it was seen that the most frequently used term for this concept was "differentiated instruction". The concept of differentiated instruction is often worked with the concepts of differentiation, assessment, special education, program, participation and learning style. Different clusters were formed in which the researchers used the keywords related to the concept of differentiated instruction together. One of them is academic achievement, learning styles and teaching strategies, assessment, multiple intelligences. Another is the cluster of the keywords differentiation, literacy, reading comprehension, reading, flipped classroom, teaching, language. Looking at the keywords that differentiated instruction is used together, it can be said that these keywords are closely related to the theories and approaches on which the theoretical foundations of differentiated instruction are based. It is stated that the common characteristics of the theories at the heart of differentiated instruction are the multiple intelligence theory emphasizing individual differences and approaches related to learning style (Turville, Allan, \& Nickelsen, 2010). In the researches, it is seen that the keywords emphasizing the individual differences that constitute the theoretical foundations of differentiated instruction are clustered. In addition, the results obtained in the analysis of keywords in this research are partially consistent with the finding that the thesis in the field of differentiated instruction is generally concentrated on the themes of math teaching, academic achievement and teacher education (Karadağ, 2014).

As a result of bibliographic coupling of the sources, it is seen that the first two journals about differentiated instruction are "teaching and teacher education" and "teachers and teaching". Other important journals in this field are "studies in educational evaluation", "international journal of instruction", "international journal of inclusive education", "journal of advanced academics", "journal for the education of the gifted", "professional development in education" , "Inted2016", "gifted child quarterly", "theory into practice", "reading teacher", "international journal of emerging technologies in learning" and "Russian education and society". Although all resources are in a citation relationship with each other, it can be stated that "teaching and teacher education" and "teachers and teaching" resources are more centralized in differentiated instruction.

Having examined the bibliographic coupling of the countries, it is seen that the country with the most publications on differentiated instruction is the USA. Following the USA, countries with the most publications on this issue are Canada, Belgium, Australia, Netherlands, Turkey, Greece, Germany, China, South Africa, Singapore, England, Romania, Spain, Brazil, and Ukraine. The most prominent countries on differentiated instruction in recent years have been identified as Netherlands, Germany and Ukraine. Differentiated instruction, one of the approaches sensitive to individual differences, attracts the attention of researchers in many countries around the world. However, this issue has attracted the attention of researchers in the USA more than anywhere else in the world. Since the second half of the 20th century, more flexible and applied education programs have been adopted in the USA with changes in educational philosophy (Bas, 2013). In this context, approaches sensitive to individual differences, especially the principles of the theory of multiple intelligences, have become widespread in schools (Armstrong, 2009). The researchers' interest in fundamentally modern learning approaches may have led them to be interested in the differentiated instruction approach as well.

When the bibliographic coupling of the authors was examined, it was determined that the first four of the most effective authors in differentiated instruction were R. Vanderlinde, F. Guay, A. Roy and P. Valois. The first three authors are those who have published more recent years on differentiated instruction. They are O. Synekop, H. Dack and A. Zusho. It has been observed that there are strong citation relationships between R. Vanderlinde, F. Guay, A. Roy and P. Valois in the field of differentiated instruction. The fact that three of these researchers work at universities in Canada may make it easier for researchers to follow up and collaborate on their research 
Santamaria (2009) was identified as the most effective publication when bibliographic coupling of the authors' publications was examined. The top 3 strongest publications were Santamaria (2009), Reis et al. (2011) and De neve et al. (2015). Although there are more cited publications in the field of differentiated instruction, it can be stated that these studies show the expected impact in the field more clearly.

Three publications of Tomlinson who introduced the concept of differentiated instruction for the first time are among the 30 most effective publications. Here are the most effective publications within their own clusters with maximum citation links to each other; Publications by Valli et al. (2007), Davies et al. (2013), Santamaria (2009) authors in the first cluster, Vaughn et al. (1998), Wertheim et al. (2002), Soodak et al. (1998), Dixon et al. (2014), De neve et al. (2015) authors' publications in the second cluster, Westberg et al. (1993), Reis et al. (2011) and Gamoran et al. (1995) in the third cluster, Baglieri et al. (2004) in the fourth and Subban (2006) in the fifth cluster. The connections of common citations between articles may have been effective in forming these clusters in this way.

In the bibliographic coupling of institutions, it was seen that the top 10 of the most effective institutions in publications on differentiated instruction were Ghent University, Brussel University, Amsterdam University, Groningen University, Virginia University, Leiden University, Ohio State University, Connecticut University, Ottawa University, Melbourne University. It is seen that the first two universities in the front rank are also in Belgium. The bibliographic coupling, which reveals that the three most influential authors in this field work in Belgium and two of the three authors are within Ghent University, confirms this finding. Among the 10 most influential institutions in this field are two from Belgium, three from the Netherlands, three from the USA, one from Australia and one from Canada.

In the co-citation analysis of the authors, it was determined that the first of the most co-cited authors in the field of differentiated instruction was C.A. Tomlinson who first introduced the concept of differentiated instruction. The authors with the most co-cited after Tomlinson were determined as Gardner, Reis and Vygotsky, respectively. This is the expected result that researcher Tomlinson, who introduced the concept of differentiated instruction, is stand out in the citation analysis. In addition, the fact that Gardner, the defender of the theory of multiple intelligences, and Vygotsky, the inventor of the term zone of Proximal Development, and Tomlinson are mentioned together in the field of differentiated instruction also reveal the theoretical foundations on which differentiated instruction is based (Avc1, \& Yüksel, 2014; Subban, 2006; Turville, Alan, \& Nickelsen, 2010).

As a result of the co-citation analysis of the sources, the sources with the most co-cited in the field of differentiated instruction were determined as "teacher and teaching education", "educational leadership" and "journal for the education of the gifted", respectively. The prominent resources in the field of differentiated instruction will contribute to new researchers in terms of following effective publications.

As a result of the co-citation analysis of the publications, it was determined that the first three of publications with the most co-cited in the field of differentiated instruction were Tomlinson's publications in 1999, 2001 and 2003. The presentation of these researches, which have the expected effect in the field of differentiated instruction, will make an important contribution to establishing the theoretical framework, especially for researchers who will conduct new research or write thesis.

Developments in teaching and learning activities reveal the need for educational activities that can meet the needs of students. The fact that this point is seen within the subject area of differentiated instruction (Tomlinson, 1999) has increased the interest in this field. In this study, data obtained from one of the most reputable databases were analyzed in order to obtain important scientific information. The results of this study, which gives an idea about the trends of scientific studies in the field of differentiated instruction, are thought to contribute to the differentiated instruction literature.

\section{Ethical Declaration}

In the writing process of the study titled "Differentiated Instruction: Bibliometric Map of Literature", there were followed the scientific, ethical and the citation rules; was not made any falsification on the collected data and this study was not sent to any other academic media for evaluation. Since the document review was conducted in this study, there is no need for an ethics committee decision. 


\section{References}

Al, U. (2008). Türkiye'nin bilimsel yayin politikasi: Atif dizinlerine dayali bibliyometrik bir yaklaşim. Yayınlanmamıs doktora tęi. Hacettepe Üniversitesi, Sosyal Bilimler Enstitüsü, Ankara.

Armstrong, T. (2009). Multiple intelligences in the classroom (3rd Edition). ASCD.

Avc1, S. \& Yüksel, A. (2016). Farklilaştırlmış ögretim teori ve uygulama. Ankara: Nobel Yayıncılık

Bas, G. (2013). Amerika Birleşik Devletleri egitim sistemi: Karşılaştırmalı bir çalısma. Journal of Educational Science, 1(1) , 63-93. Retrieved from https://dergipark.org.tr/tr/pub/jedus/issue/16124/168706

Cobo, M. J., Lopez-Herrera, A. G., Herrera-Viedma, E., \& Herrera, F. (2011). Science mapping software tools: Review, analysis, and cooperative study among tools. Journal of the American Society for Information Science and Technology, 62 (7), 1382-1402.

Çïlhoroz, Y. \& Arslan, İ. (2018). Yalın yönetim yaklaşımı ve sağlık hizmetlerinde uygulamaları. Süleyman Demirel Üniversitesi Sosyal Bilimler Enstitüsü Dergisi, 1(32), 156-185. Retrieved from https://dergipark.org.tr/tr/pub/sbe/issue/41366/430985

Davies, R. S., Dean, D. L., \& Ball, N. (2013). Flipping the classroom and instructional technology integration in a college-level information systems spreadsheet course. Educational Technology Research and Development, 61(4), 563580.

De Neve, D., Devos, G., \& Tuytens, M. (2015). The importance of job resources and self-efficacy for beginning teachers' professional learning in differentiated instruction. Teaching and teacher education, 47, 30-41.

Demir, H., \& Erigüç, G. (2018). Bibliyometrik bir analiz ile yönetim düşünce sisteminin incelenmesi. İs ve Insan Dergisi, 5(2), 91-114.

Dixon, F. A., Yssel, N., McConnell, J. M., \& Hardin, T. (2014). Differentiated instruction, professional development, and teacher efficacy. Journal for the Education of the Gifted, 37(2), 111-127.

Gamoran, A., Nystrand, M., Berends, M., \& LePore, P. C. (1995). An organizational analysis of the effects of ability grouping. American Educational Research Journal, 32(4), 687-715.

Garfield E. (1988). Announcing the SCI Compact Disc Edition: CD-ROM Gigabyte Storage Technology, Novel Software, and Bibliographic Coupling Make Desktop Research and Discovery a Reality. Current Contents, 22, 313. Retrieved from: http://www.garfield.library.upenn.edu/essays/v11p160y1988.pdf

Goksu, I. (2020). Bibliometric mapping of mobile learning. Telematics and Informatics, 101491.

Hall, T., Strangman, N., \& Meyer, A. (2003). Differentiated instruction and implications for UDL implementation. National Center on Accessing the General Curriculum, 2-22.

Heacox, D. (2002). Differentiating instruction in the regular classroom: How to reach and teach all learners, grades 3-12. Minneapolis, MN: Free Spirit.

Hollas, B. (2005). Differentiating instruction in a whole-group setting. Peterborough, NH: Crystal Springs Books.

Karadağ, R. (2014). Dünyada ve Türkiye'de farklılaştırılmıs öğretimle ilgili yapılmış çalışmaların değerlendirilmesi. Kastamonu Eğitim Dergisi, 22(3), 1301-1322.

Kessler, M. M. (1963). Bibliographic coupling between scientific papers. American Documentation, 14(1), 10-25

Koehler, W. (2001). Information science as "Little Science":The implications of a bibliometric analysis of the Journal of the American Society for Information Science. Scientometrics 51, 117-132.

Noyons, E., Moed, H., \& Raan, A.V. (2006). Integrating research performance analysis and science mapping. Scientometrics, 46, 591-604.

Özçınar, H. (2017). Hesaplamalı düşünme araştırmalarının bibliyometrik analizi. Eğitim Teknolojisi Kuram ve Uygulama, $7(2), 149-171$.

Park, S. (2005). Student engagement and classroom variables in improving mathematics achievement. Asia Pacific Education Review, 6(1), 87-97.

Reis, S. M., McCoach, D. B., Little, C. A., Muller, L. M., \& Kaniskan, R. B. (2011). The effects of differentiated instruction and enrichment pedagogy on reading achievement in five elementary schools. American Educational Research Journal,48(2), 462-501.

Santamaria, L. J. (2009). Culturally responsive differentiated instruction: Narrowing gaps between best pedagogical practices benefiting all learners. Teachers College Record, 111(1), 214-247.

Small, H. (1973). Co-citation in the scientific literature: A new measure of the relationship between two documents. Journal of the American Society for information Science, 24(4), 265-269.

Smith, D. R. (2007). Historical development of the journal impact factor and its relevance for occupational health. Industrial Health, 45(6): 730-742.

Soodak, L. C., Podell, D. M., \& Lehman, L. R. (1998). Teacher, student, and school attributes as predictors of teachers' responses to inclusion. The Journal of Special Education, 31(4), 480-497.

Subban, P. (2006). Differentiated instruction: A research basis. International Education Journal, 7(7), 935-947. Retrieved from: https:// files.eric.ed.gov/ fulltext/EJ854351.pdf

Tieso, C. (2005). The effects of grouping practices and curricular adjustments on achievement. Journal for the Education of the Gifted, 29, 60-89.

Tomlinson, C. (1999). The differentiated classroom: Responding to the needs of all learners. USA: ASCD.

Tomlinson, C. A., \& Allan, S. D. (2000). Leadership for differentiating schools \& classrooms. Alexandria, VA: Association for Supervision and Curriculum Development. 
Tomlinson, C. A. \& Jarvis, J. (2009). Differentiation: Making curriculum work for all students through responsive planning and instruction. In J. S. Renzulli, E. J. Gubbins, K. S. McMillen, R. D. Eckert \& C. A. Little (Eds.), Systems and models for developing programs for the gifted and talented (pp. 599-628). Storrs, CT: Creative Learning Press.

Tomlinson, C. A. (2000). Differentiation of Instruction in the Elementary Grades. ERIC Digest. 1-7. Retrieved from: https:/ / files.eric.ed.gov/ fulltext/ED443572.pdf

Turville, J., Allen L., \& Nickelsen L. (2010). Differentiating by readiness: Strategies and lesson plans for tiered instruction grades K-8. NY: Eye On Education Larchmont.

Ukşul, E. (2016). Türkiye'de eğitimde ölşme ve değerlendirme alanında yapılmus bilimsel yayınlarn sosyal ăg analiẓi ile değerlendirilmesi: Bir bibliyometrik çalıs̆ma (Yüksek Lisans Tezi). Akdeniz Üniversitesi Eğitim Bilimleri Enstitüsü, Antalya.

Valiandes, S. (2015). Evaluating the impact of differentiated instruction on literacy and reading in mixed ability classrooms: Quality and equity dimensions of education effectiveness. Studies in Educational Evaluation, 45, 17-26.

Valli, L., \& Buese, D. (2007). The changing roles of teachers in an era of high-stakes accountability. American Educational Research Journal, 44(3), 519-558.

Van Eck, N. J. (2011). Methodological advances in bibliometric mapping of science (Doctoral Dissertation). Erasmus Research Institute of Management (ERIM).

Vaughn, S., Moody, S. W., \& Schumm, J. S. (1998). Broken promises: Reading instruction in the resource room. Exceptional children, 64(2), 211-225.

Wertheim, C., \& Leyser, Y. (2002). Efficacy beliefs, background variables, and differentiated instruction of Israeli prospective teachers. The Journal of Educational Research, 96(1), 54-63.

Westberg, K. L., Archambault Jr, F. X., Dobyns, S. M., \& Salvin, T. J. (1993). The classroom practices observation study. Journal for the Education of the Gifted, 16(2), 120-146.

White, H. D., \& McCain, K. W. (1998). Visualizing a discipline: An author co-citation analysis of information science, 1972-1995. Journal of the American society for information science, 49(4), 327-355.

\section{TÜRKÇE GENİ̧̧ ÖZET}

Öğrencilerin öğrenmelerini geliştiren ve başarılarını etkileyen faktörler incelendiğinde sınıf büyüklüğünden öğretmenlerin tecrübesine kadar etkili olan birçok faktör içerisinden daha etkili olanın öğretmenlerin ortaya koyacağı öğretimin niteliği olduğu ifade edilebilir (Park, 2005). Öğretimin niteliği ise ögretmenlerin bireylerin özelliklerini, yeteneklerini, hazırbulunuşluklarını, ilgi ve isteklerini dikkate alarak yapılan planlamalar ile yakından ilişkilidir. Bu bağlamda farklılaştırılmış öğretim öğrencilerin ilgi, ihtiyaç, yetenek ve bilgilerini ön planda tutan çağdaş bir yaklaşım olarak öne çıkmaktadır (Hollas, 2005; Valiandes, 2015). Farklılaştırlmış öğretim, programda yer alan içerik, süreç ve ürün boyutlarında uyarlamalar yoluyla programı, ögrencilerin hazırbulunuşluk düzeyleri, ilgi, ihtiyaç ve öğrenme profilleri ile uyumlu hale getirmeye olanak sağlar (Tomlinson, 2003; Hall, Strangman, Meyer, 2003; Tomlinson \& Jarvis, 2009). Farklılaştırılmış ögretim öğrencilerin bireysel gelişimlerinin dikkate alındığı bir yaklaşım olması sebebiyle, öğrencilerin başarıya ulaşabilecekleri koşulları kolaylaştırmanın yanında kişisel gelişimlerine de katkı sunar (Tomlinson ve Allan, 2000). Bunları esnek öğrenme ortamları, ihtiyaçların süreç içerisinde değerlendirilmesi, esnek gruplar, bireysel zorlayıc1 görevler ve işbirlikli öğrenme grupları gibi ilkeleri sayesinde sağlar (Tomlinson, 1999).

Bu çalışmanın amacı, farklılaştırılmış ögretime ilişkin yayınların analiz edilerek bu alandaki literatürün gelişimine katkı sağlamaktır. Araştırmanın bir başka amacı da farklılaştırılıış öğretim ile ilgili yayınları sistematik olarak incelemektir. Yapılan yayınların eğilimlerini ortaya çıkarabilmek amacıyla bibliyometrik analiz kullanılmıştır. Bibliyometrik yöntemler bilimsel alanda yapılan araştırmaların yönelimini, alana yönelik gelişmeleri ve alanın yapısını çeşitli sınıflandırmalarla ortaya çıkarmaktadır (Demir ve Erigüç, 2018). Çalışmada bilimsel yayınların dünyadaki en prestijli olanlarının yer aldığı Web of Science (WoS) veri tabanı kullanılmıştır. WoS veri tabanı tıpkı Scopus, Google Scholar gibi birçok veri tabanından biridir. Ancak araştırmada Wos'un tercih edilmesinin nedeni sosyal bilimlere ait etki faktörü yüksek çok sayıda dergi içermesi ve araştırmacılara analiz yapabilecekleri kolaylıklar sunmasıdır.

WoS veri tabanının gelişmiş arama özelliği kullanılarak Kasım 2020 tarihine kadar yapılan tüm araştırmalar taranmıştır. Arama yapılırken "differentiated instruction" "differentiated learning", "differentiated teaching" ve "differentiated classroom" kavramları aratılmıştır. Sonuç olarak toplam 667 yayın analiz birimini oluşturmuştur. Araştırmaya dahil olan yayınlar, kendi aralarındaki matematiksel ilişkileri temel alarak bibliyometrik görselleştirme yöntemiyle sunulmuştur. Yazarların kullandıkları ortak anahtar kelimelerin analizi araştırma alanının alt alanları ve eğilimlerin ortaya konmasında önemlidir (Özçınar, 2017). Atıf analizi yayınlar, yazarlar ve dergiler arasından etkili olanlarının belirlenmesi ve birbirleri ile ilişkilerinin ortaya konmasında ve araştırma alanının tarihsel durumunu ortaya koymada 
önemlidir (Goksu, 2020). Bibliyografik eşleşmeler yayın, yazar, ya da dergi boyutunda ortaya koyulabilmektedir. Bibliyografik eşleşmelerin amacı alanın bilişsel yapısını ve alanın yapısındaki değişmeleri ortaya koymaktır (Özçınar, 2017). Bu analizde iki yazar ya da iki yayın üçüncü bir yayından aynı anda atıf alırsa bu iki yayının veya yazarın bibliyografik eşleşme sağladığı şeklinde yorumlanmaktadır.

Yapılan bibliyografik eşleşme analizlerinin sonucunda yazarların ortak olarak kullandıkları anahtar kelimelerin bibliyografik eşleşmesinde, bu kavram için en sık kullanılan terimin "farklılaştırılmış öğretim" olduğu görülmüsşür. Farklılaştırllmış öğretim kavramı sıklıkla farklılaştırma, değerlendirme, özel eğitim, program, katılım ve öğrenme stili kavramlarıla birlikte çalışlmaktadır. Kaynakların bibliyografik eşleştirilmesi sonucu farklılaştırılmış öğretim ile ilgili ön plana çıkan dergilerin ilk ikisinin "teaching and teacher education" ve "teachers and teaching" olduğu görülmektedir. Ülkelerin bibliyografik eşleşmeleri incelendiğinde farklılaştırılmış öğretim konusunda en çok yayın yapılan ülkenin ABD olduğu görülmektedir. ABD nin ardından bu konuda en çok yayın diğer ülkeler ise Kanada, Belçika, Avustralya, Hollanda, Türkiye, Yunanistan, Almanya, Çin, Güney Afrika, Singapur, İngiltere, Romanya, İspanya, Brezilya, Ukrayna olarak sıralanmaktadır. Son yıllarda farklılaştırılımış öğretim konusunda en çok yayın yapan ülkelerden öne çıkanlar ise Hollanda, Almanya ve Ukrayna olarak tespit edilmiştir. Yazarların bibliyografik eşleştirmeleri incelendiğinde farklılaştırılmış öğretim konusunda en etkili yazarlardan ilk üçünün R. Vanderlinde, F. Guay, A. Roy olduğu belirlenmiştir. Yazarlara ait yayınların bibliyografik eşleşmesi incelendiğinde Santamaria (2009) en etkili yayın olarak tespit edilmiştir. En güçlü ilk 3 yayın ise Santamaria (2009), Reis vd. (2011) ve De neve vd. (2015) yazarlarının yayınları olarak belirlenmiştir. Kurumların bibliyografik eşleşmesi farklılaştırılmış öğretim konusunda yapılan yayınlarda en etkili kurumlardan ilk 10'unun siralamasinın Ghent Üniversity, Brussel University, Amsterdam University, Groningen University, Virginia University, Leiden University, Ohio State University, Connecticut University, Ottowa University, Melbourne University olduğu görülmüsstür. Ön sıralarda yer alan ilk iki üniversitenin de Belçika'da yer aldığı görülmektedir.

Yapılan ortak atıf analizleri neticesinde farklılaştırılmış öğretim alanında en çok atıf alan yazarlardan ilkinin farklılaştırılmış öğretim kavramını ilk kullanan isim C.A. Tomlinson olduğu belirlenmiştir. Tomlinson'dan sonra en çok alıntı yapılan yazarlar sırasıyla Gardner, Reis ve Vygotsky olarak belirlendi. Kaynakların ortak atıf analizi sonucunda farklılaştırılmış öğretim alanında en çok atıf yapılan kaynaklar sirasiyla "teacher and teaching education", "educational leadership" ve "journal for the education of the gifted" olarak belirlenmiştir. Yayınların ortak atıf analizi sonucunda, farklılaştırlmış öğretim alanında en çok atıf alan yayınlardan ilk üçünün 1999, 2001 ve 2003 yıllarında Tomlinson tarafindan yapılan yayınlar olduğu belirlenmiştir.

Eğitim ve ögrretim faaliyetlerinde öne çıkan gelişmelerin ortaya koyduğu, öğrencilerin ihtiyaçlarına cevap verebilecek niteliğe sahip eğitim öğretim çalışmalarına olan ihtiyaç, farklılaştırılmış öğretimin konu alanı olarak görüldüğünden (Tomlinson, 1999) bu alana olan ilgiyi arttırmıştır. Farklılaştırılmış öğretim alanındaki bilimsel çalışmaların eğilimleri konusunda fikir veren bu çalışmanın sonuçlarının farklılaştırılmış öğretim literatürüne de katk1 sunacağ1 düşünülmektedir. 